\title{
Suppressed Undergrowth of Siberian Spruce (Picea obovata Ledeb.) in Early Ontogeny: One-Way Ticket or Survival Strategy?
}

\author{
Gleb Zaitsev ${ }^{1, *(D)}$, Alexander Davydychev ${ }^{1}$, Alexey Kulagin ${ }^{1}$, Rafak Giniyatullin ${ }^{1}$, Ruslan Suleymanov ${ }^{2}(\mathbb{D}$, \\ Andrey Kulagin ${ }^{3}$, Natalya Egorova ${ }^{1}$, Mikhail Komissarov ${ }^{1}{ }^{1}$, Ruslan Urazgildin ${ }^{1}$ and Olesya Tagirova ${ }^{3}$ \\ 1 Ufa Institute of Biology, Ufa Federal Research Centre, Russian Academy of Sciences, 450054 Ufa, Russia; \\ shur25@yandex.ru (A.D.); coolagin@list.ru (A.K.); grafak2012@yandex.ru (R.G.); \\ natalja.eg2010@yandex.ru (N.E.); mkomissarov@list.ru (M.K.); urv@anrb.ru (R.U.) \\ 2 Department of Geodesy, Cartography and Geographic Information Systems, Bashkir State University, \\ 450076 Ufa, Russia; soils@mail.ru \\ 3 Department of Ecology, Geography and Nature Management, Akmulla Bashkir State Pedagogical University, \\ 450008 Ufa, Russia; kulagin-aa@mail.ru (A.K.); olecyi@mail.ru (O.T.) \\ * Correspondence: forestry@mail.ru
}

Citation: Zaitsev, G.; Davydychev, A.; Kulagin, A.; Giniyatullin, R.; Suleymanov, R.; Kulagin, A.; Egorova, N.; Komissarov, M.; Urazgildin, R.;

Tagirova, O. Suppressed

Undergrowth of Siberian Spruce

(Picea obovata Ledeb.) in Early Ontogeny: One-Way Ticket or Survival Strategy? Forests 2021, 12, 851. https://doi.org/10.3390/ f12070851

Academic Editor: Brian J. Palik

Received: 26 May 2021

Accepted: 24 June 2021

Published: 28 June 2021

Publisher's Note: MDPI stays neutral with regard to jurisdictional claims in published maps and institutional affiliations.

Copyright: (c) 2021 by the authors. Licensee MDPI, Basel, Switzerland. This article is an open access article distributed under the terms and conditions of the Creative Commons Attribution (CC BY) license (https:// creativecommons.org/licenses/by/ $4.0 /)$

\begin{abstract}
The study examined the growth characteristics of the Siberian spruce (Picea obovata Ledeb.) under the canopy of coniferous forests in early ontogeny. We revealed that spruce undergrowth in adverse conditions is suppressed, is slow to grow and has xylorhizomes. The result is a significant difference in height, age and stage of ontogeny that affects the forest's growth dynamics. The formation of xylorhizomes changes the relative dimensions of the above-ground part and the plant's absolute height from 42 to $75 \%$, depending on age. We identified two periods of growth intensity (slow and stable) and the critical age for spruce undergrowth to move from one stage of ontogeny to the next. If it does not make the transition, it will die. There are two strategies for developing spruce undergrowth: a "direct" path during rapid growth and a "waiting" path when the plants are suppressed. Such growth pathways in the pre-generative stage of the Siberian spruce's ontogeny allow the undergrowth, even in a suppressed state, to survive in an adverse environment under the forest canopy.
\end{abstract}

Keywords: coniferous forests; forest regeneration; understory tolerance; pre-generative ontogeny

\section{Introduction}

Tree growth is a prolonged and complex process involving multiple ontogenetic stages from germination to maturity [1]. The initial stages are the most critical [2] because they determine growth and, as a result, the development of sustainable forest ecosystems.

Natural forest regeneration is influenced by density [3], age [4], canopy closeness and understory state [5,6], microsite condition [7], soil temperature [8], undergrowth spread [9], and wildfire [10]. Since the maximum sun availability is at the top of a canopy, light levels are lessened exponentially with each vegetation layer [11]. Therefore, light is crucial to the successful regeneration of trees under a closed canopy.

Siberian spruce (Picea obovata Ledeb.) represents a constituent of the boreal taiga that extends across millions of square kilometers in eastern European Russia and Siberia. As one of the major tree species in Russia (and perhaps in the world), it represents the largest standing timber resource by volume [12]. On the Ufa Plateau, Siberian spruce and other conifers form extensive forests.

The spruce genus (picea) contains the most light-dependent tree species, and their regeneration is strongly affected by basal area or canopy density [13]. Furthermore, spruce is more substrate-restricted than other tree species because its seeds are tiny [14]. The bryophyte cover affords a safe micro-habitat for tree seedlings and makes a good seedbed 
for conifers [15]. Based on an analysis of the moss cover, it directly affected coniferous seedling height when it was at a depth of less than $4 \mathrm{~cm}$ [16]; however, an excessively thick moss cover adversely affects the emergence and survival of current-year seedlings [17-19]. Moreover, previous studies have shown that decaying logs are suitable seedbeds for tree seedlings and that conifer undergrowth occurred much more frequently on trunks than in soil [20-23].

Below the forest canopy, extreme light deficiency affects the development of tree undergrowth. Shade tolerance diminishes with age [24] and is associated with an extension in the proportion of a plant's non-photosynthetic parts (roots, branches); minimal light and nutrient availability promotes depressed growth.

The ability to persist for a long time in juvenile, immature or mature virginile stages are peculiar to many typical violent species [25]. Most published studies have tried to estimate the age of Picea species based on classical methods, such as calculating the annual growth of branches [26] or counting rings at ground level [27-29], but since there are no earliest annual rings, it is difficult to ascertain the year of suppressed undergrowth, which can lead to significant mistakes in age measurement [30-32]. There is some evidence that the regeneration of spruce in broad-leaved coniferous forests [33] and fir (Abies sibirica Ledeb.) in coniferous forests [34] occurs unsatisfactorily: undergrowth is depressed and stunted, and xylorhizomes form.

Forests are critical for the sustainability of ecological systems and climate protection, especially in carbon sequestration [35-38]. Because Siberian spruce is one of the world's primary timber species, studying the characteristics of its regeneration and forming sustainable forest ecosystems with it is especially relevant. The ontogeny of various Pinaceae species has been studied in some detail [39-44], but that of the Siberian spruce is not well understood [45-47]. Therefore, the characteristics of its growth in early ontogeny is a focus of current research.

\section{Materials and Methods}

\subsection{Site Descriptions}

The sites of this study are four mature natural conifer forests on the Ufa Plateau, which is within the water-protection zone of the Pavlovka Reservoir (Ufa River). The location of each site is shown in Figure 1. The Ufa Plateau, in the eastern part of Central Russia and west of the Ural Mountains, is located in the Ufa River basin, rising 150-200 m above the surrounding areas to an absolute height of $400-450 \mathrm{~m}$. We have presented the physiographic and climatic characteristics of the Ufa Plateau before [33,34,48].

Studies that have been carried out in coniferous forests (closed mature forests with mossy ground cover) are summarized in Table 1. Extensive bryophyte mats dominated by the green mosses Pleurozium schreberii (Brid.) Mitt., Hylocomium splendens (Hedw.) Lindb., H. polysetum (Hedw.) Lindb, Dicranum scoparium Hedw., D. polysetum Sw. (Hedw.) De Not., Ptilium crista-castrensis (Hedw.) De Not., and Rhodobrium roseum (Hedw.) Limpr. 

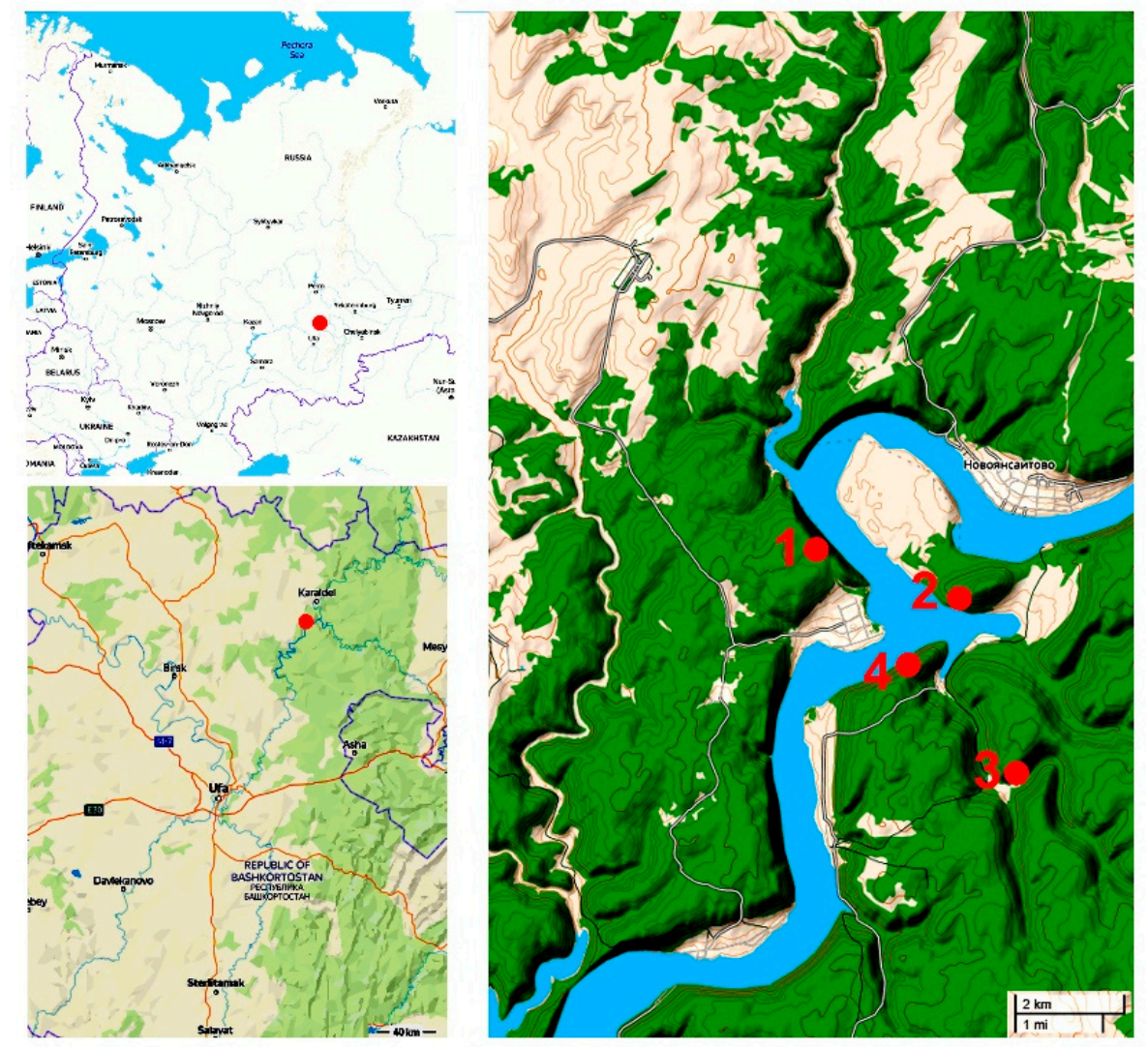

Figure 1. (Left): location of the study area on the Ufa plateau (red points); (right): the position of the spruce-moss forest (1), fir-spruce-moss forest (2), pine-moss forest (3), and larch-moss forest (4) around the Pavlovka Reservoir.

Table 1. Description of the forest sites studied.

\begin{tabular}{|c|c|c|c|c|c|c|}
\hline Stand Formula * & Age, Years & Stand Density & Growth Class & Tree Height, m & $\begin{array}{c}\text { Tree Diameter, } \\
\text { cm }\end{array}$ & $\begin{array}{c}\text { Amount of Spruce } \\
\text { Undergrowth, } 1000 \\
\text { Stems Per } \mathrm{Ha}\end{array}$ \\
\hline \multicolumn{7}{|c|}{ Spruce-moss forest } \\
\hline 1 layer: $10 \mathrm{~S}$ sngl: $B, P, \mathrm{Ln}$ & 130 & 0.40 & \multirow[t]{2}{*}{ III } & $\begin{array}{c}28.2 \\
0.5\end{array}$ & 24.2 & \multirow[t]{2}{*}{$8.6\left(2.2^{* *}\right)$} \\
\hline 2 layer: 5S4B1Ln sngl. F & & 0.10 & & & & \\
\hline \multicolumn{7}{|c|}{ Fir-spruce-moss forest } \\
\hline \multirow{2}{*}{$\begin{array}{l}1 \text { layer: 5F5S sngl. B, } P \\
2 \text { layer: } 10 \mathrm{~F}+\mathrm{S}, \mathrm{Ln}, \mathrm{B} \text { sngl. } \\
\mathrm{M}, \mathrm{W}\end{array}$} & 90 & 0.79 & \multirow{2}{*}{ II } & 21.6 & 20.4 & \multirow{2}{*}{$15.0(0.6)$} \\
\hline & 70 & 0.06 & & 9.9 & 8.7 & \\
\hline \multicolumn{7}{|c|}{ Pine-moss forest } \\
\hline 1 layer: 7P3S +B, sngl. Ln & 136 & 0.60 & \multirow{2}{*}{ III } & 27.0 & 19.8 & \multirow{2}{*}{$5.0(1.1)$} \\
\hline 2 layer: 5S3P2B + Ln sngl. F & 65 & 0.20 & & 9.6 & 9.0 & \\
\hline \multicolumn{7}{|c|}{ Larch-moss forest } \\
\hline 1 layer: 5Lr4S1B sngl. $\mathrm{P}$ & 110 & 0.5 & \multirow[b]{2}{*}{ V } & 19.1 & 15.2 & \multirow{2}{*}{$23.6(0.4)$} \\
\hline 2 layer: 6S3B1 Lr + F & 80 & 0.5 & & 9.1 & 9.2 & \\
\hline
\end{tabular}

* Spruce-moss forest: 1 layer: 10 Spruce, single: Birch, Pine, Linden; 2 layer: 5 Spruce, 4 Birch, 1 Linden, single: Fir. Fir-spruce-moss forest: 1 layer: 5 Fir, 5 Spruce, single: Birch, Pine; 2 layer: 10 Fir + S, Linden, Birch, single: Maple, Willow. Pine-moss forest: 1 layer: 7 Pine, 3 Spruce + Birch, single: Linden; 2 layer: 5 Spruce, 3 Pine, 2 Birch + Linden, single: Fir. Larch-moss forest: 1 layer: 5 Larch, 4 Spruce, 1 Birch, single: Pine; 2 layer: 6 Spruce, 3 Birch, 1 Larch + Fir. ${ }^{* *}$ Amount of large undergrowth.

A fir-spruce-moss forest (FSMF) is associated with slopes having southern, southeastern and southwestern exposures and with sustainably wetted humus-carbonate mountainforest soil developed on the sediments of limestone rubble-clay diluvia. In addition to mosses, the living ground cover features various species of sedge (Carex digitata L., C. macroura Meinch., C. muricata L., and C. rhizina Blytt ex Lindbl.), a common forest growth 
found on $20 \%$ of the investigated territory. A spruce-moss forest (SMF) grows on steep, shady slopes with humus-carbonate mountain-forest soil formed on loamy, rubble of large blocks, eluvio-deluvia limestone deposits. In the grass layer, various species of small fern (Gymnocarpium dryopteris (L.) Newm., G. robertianum (Hoffm.) C.Chr.) cover about 8\% of the area. Pine-moss (PM) and larch-moss (LM) forests occupy slopes with perennially frozen soil (permafrost), which are unique for this altitude, latitude and longitude $[49,50]$. In all cases, these soils are formed on the lower part of the steep slopes of the Ufa River valley, rarely on the slopes of the small river valleys of the Ufa River tributaries. The frozen ground is characterized by steadily wetted peat-humus mountain-forest soils formed by deposits of rubble-clay eluvio-deluvia and large blocks of gravel and limestone eluvia. The south-facing slopes have pine forests (Pinus sylvestris L.) with Siberian death camas (Anticlea sibirica (L.) Kunth. syn. Zigadenus sibiricus (L.) A. Gray) in the grass layer, whereas the larch forests (Larix sukaczewii Dyl.) on the north-facing slopes have widespread sphagnum (Sphagnum capillipholium (Ehrh.) Hedw.) in the grass layer. PM and LM forests have adverse conditions and occupy the smallest area (less than $3 \%$ and $2 \%$, respectively).

\subsection{Sample Collection and Analysis}

Research in the study area was conducted from 2008 to 2020. Three trial plots were laid out for each type of forest for a total of 12 . There was no consistent approach to the size of the plots: large plots are more time-consuming and expensive, whereas small ones are not large enough to characterize the forests comprehensively [51,52]. In our case, we used the most commonly practiced 0.25 ha trial plots $(50 \times 50 \mathrm{~m})[53,54]$.

The forest inventory was based on standard method guidelines [55,56]. The stand density was determined by the commonly used measure of the total basal area of all trees [52]. There is a distinction between the absolute and relative density of forest stands. Absolute density is expressed as the sum of the cross-sectional areas of all trees in the stand $\left(\mathrm{m}^{2}\right.$ per ha) at breast height. Relative stand density is expressed as a decimal places of unit. The completely closed stand, optimal for the age, height and habitat conditions of a particular tree species was taken as a unit. In our work, we determined the relative stand density. Growth class (also called bonitet) is an inventory feature that defines the possible productivity of a stand and the growth rate of trees. It is determined using the Orlov table [57], and depends on the average age and height of trees and the stand origin (seminal or vegetative). The higher the height of stand at the age considered, the higher the growth class, which is visually determined by the distance between the whorls, taking into account the age and height of the stand. Class I and II stands are high-growth class; class III-IV is medium growth; class $\mathrm{V}$ is low growth; and classes $\mathrm{Va}$ and $\mathrm{Vb}$ are unproductive. The stand formula, which describes the tree species composition of the forest, was determined based on the stock volume [57]. Each species' portion in the volume was defined by a composition coefficient (in integers), and an abbreviated name (first letter) was assigned to each species. The sum of all coefficients is 10 , i.e., $100 \%$ of the stand stock volume. If the stock of a tree species is between 2 and $5 \%$ of the total forest stock, it is marked with a "+" symbol in the formula. If the stock is less than $2 \%$, it is marked as "single".

The quantity of spruce undergrowth throughout the research period was determined three times (in 2008, 2013 and 2019) and followed by data averaging. For this purpose, sample plots were evenly distributed within the trial plots. For small undergrowth, the sample plot was $0.25 \mathrm{~m}^{2}$; for large undergrowth, $4 \mathrm{~m}^{2}$. Each trial plot had 40 sample plots for small undergrowth and 20 sample plots for large.

Each year, plants were selected for analysis at random from sample plots. The principle was that all possible habitats with different light modes (shady, medium-shady and open) and ground cover (moss mats, grass cover and fallen trunks) should be represented. The number of sample plots for each forest type was at least 30 each year. The plant samples were collected and processed following the Pridnya [58] method recommendations for Siberian spruce. Within each type of forest, 20-40 samples of spruce undergrowth were 
collected. In total, we collected and examined 905 juvenile plants, 1391 immature plants and 294 virginile plants.

Illumination under the canopy was measured at noon for 12-14 h using a light meter (TKA-Lux, Russia). The luminance level inside the trial plots ranged from 500-1500 lx (shady habitats) and 1501-15,000 lx (medium-shady) to 15,001-50,000 lx (open and forest gaps). In general, depending on the luminance level below the canopy, the forests were placed in the following row (minimum to maximum values): SMF-LMF- FSMF-PMF.

According to the aboveground height, the undergrowth was divided into small (up to $50 \mathrm{~cm}$ ) and large (over $50 \mathrm{~cm}$ ). We estimated the height of plants in the field using a measuring tape with an accuracy of $0.5 \mathrm{~cm}$. For each collected plant, the hypocotyl location was determined, which was necessary to define the ratio of the above and underground parts of the spruce undergrowth and calculate its exact age. In the laboratory, a digital caliper with an accuracy of $0.5 \mathrm{~mm}$ was used to measure the length of small undergrowth; a measuring tape was used to measure the length of large undergrowth to within $0.1 \mathrm{~cm}$. We also noted the presence or absence of lateral and pseudo-whorl shoots to determine the age at which they begin to form. All measurements of trees height/length were performed in triplicate.

The pith node count method [32,58-60] was used to examine growth characteristics, the biological and calendar age of the undergrowth. This method is based on an anatomical analysis of the visible traces of apical buds (air cavities) on the stem's longitudinal section. The work methods (the study of apical growth, definition of biological and calendar age, description of relative growth dynamics) were reported in detail $[33,34,48]$. All data (trees height/length, diameter, density and amount) from tests were subjected to statistical processing [61], and all calculations (descriptive statistics) were conducted using MS Excel and Statistica 8.0 software. The mean with the standard error $( \pm$ SEM) was calculated and presented in graphs (Figure 2); in Tables 1-3, the measured values are averaged, and the \pm SEM there is less than $5 \%$.

Table 2. The ratio (\%) of the above-ground part (height above soil level) to the total height of the Siberian spruce (Picea obovata Ledeb.) undergrowth (together with the buried part). Range of height is in parenthesis.

\begin{tabular}{ccccc}
\hline \multirow{2}{*}{ Age, Years } & \multicolumn{4}{c}{ Forest Type } \\
\cline { 2 - 5 } & $\begin{array}{c}\text { Fir-Spruce-Moss } \\
\text { Forest }\end{array}$ & $\begin{array}{c}\text { Spruce-Moss } \\
\text { Forest }\end{array}$ & $\begin{array}{c}\text { Larch-Moss } \\
\text { Forest }\end{array}$ & $\begin{array}{c}\text { Pine-Moss } \\
\text { Forest }\end{array}$ \\
\hline $6-10$ & $71(40-94)$ & $75(32-100)$ & $50(27-79)$ & $54(38-72)$ \\
$11-15$ & $66(40-93)$ & $51(36-65)$ & $51(34-75)$ & $50(28-74)$ \\
$16-20$ & $66(32-83)$ & $66(28-84)$ & $56(38-82)$ & $46(32-63)$ \\
$21-25$ & $72(39-94)$ & $69(54-92)$ & $59(22-91)$ & $41(27-59)$ \\
$26-30$ & $74(56-88)$ & $70(61-82)$ & $57(40-74)$ & $58(42-80)$ \\
$31-35$ & $73(66-79)$ & $74(58-100)$ & $54(36-77)$ & $42(23-87)$ \\
\hline
\end{tabular}

Table 3. The distribution of the undergrowth of Siberian spruce (Picea obovata Ledeb.) along ontogeny stages (\% of the total amount of plants of this age group).

\begin{tabular}{|c|c|c|c|c|c|c|c|c|c|c|c|c|}
\hline \multirow{2}{*}{$\begin{array}{c}\text { Age Groups } \\
\text { (Biological Age) }\end{array}$} & \multicolumn{3}{|c|}{ Fir-Spruce-Moss Forest } & \multicolumn{3}{|c|}{ Spruce-Moss Forest } & \multicolumn{3}{|c|}{ Larch-Moss Forest } & \multicolumn{3}{|c|}{ Pine-Moss Forest } \\
\hline & $j$ & $i m$ & $v$ & $j$ & $i m$ & $v$ & $j$ & $i m$ & $v$ & $j$ & $i m$ & $v$ \\
\hline $2-5$ & 77 & 23 & - & 75 & 25 & - & 74 & 26 & - & 75 & 25 & - \\
\hline $6-10$ & 33 & 66 & 1 & 34 & 63 & 3 & 30 & 62 & 8 & 27 & 64 & 9 \\
\hline $11-15$ & 24 & 73 & 3 & 22 & 72 & 6 & 20 & 70 & 10 & 18 & 74 & 8 \\
\hline $16-20$ & 7 & 66 & 27 & 8 & 68 & 24 & - & 54 & 46 & - & 50 & 50 \\
\hline $21-30$ & - & 50 & 50 & - & 51 & 49 & - & 30 & 70 & - & 29 & 71 \\
\hline $31-40$ & - & 22 & 78 & - & 23 & 77 & - & 21 & 79 & - & 24 & 74 \\
\hline $41-50$ & - & 8 & 92 & - & 9 & 91 & - & - & 100 & - & - & 100 \\
\hline 51 and older & - & - & 100 & - & - & 100 & - & - & 100 & - & - & 100 \\
\hline
\end{tabular}



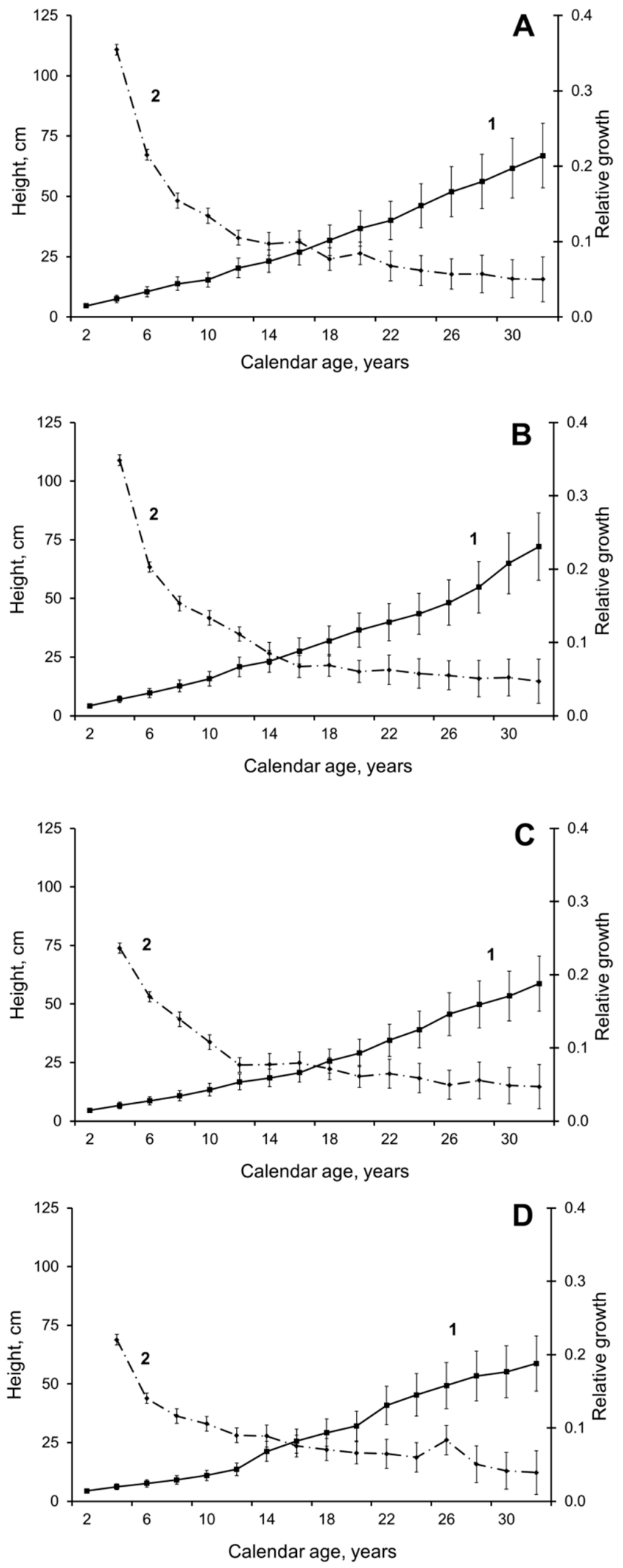

Figure 2. Growth dynamics in height (left scale) and relative growth (right scale) of the undergrowth of Siberian spruce (Picea obovata Ledeb.) in (A) fir-spruce-moss forest, (B) spruce-moss forest, (C) pine-moss forest, and (D) larch-moss forest. Curves: 1, growth dynamics; 2, relative growth. In graphs: lines (mean), error bars ( \pm SEM). 
Based on the rise and end of reproductive function, plant ontogenesis can be divided into stages (formation and development, change and death) according to their proportion in the organism [62]. Plant ontogeny stages have two peculiar classifications: one specifically for trees [63]; the other, for perennial herbaceous plants initially [64] but subsequently improved by other scientists [39,65-67], is now frequently used for a range of plant life, from trees to annuals, of varied ecological and geographical distribution [68,69]. To define the ontogeny phases of suppressed spruce undergrowth, we practiced Serebriakov's classification [39] and indicated the stages as juvenile (j), immature (im), and virginile (v).

\section{Results and Discussion}

There was insufficient regeneration of spruce under the canopy of the studied forest types. The greatest amount of small spruce undergrowth was found under the canopy of the FSMF and LMF, and the smallest under the SMF and PMF because of smaller crown density. Overall, there was a significant prevalence of small over large undergrowth: in the SMF, $25.6 \%$ of the small undergrowth passed into large undergrowth (i.e., it grew to a height $\geq 50 \mathrm{~cm}$ ) compared to $22.0 \%$ in the PMF, $4.0 \%$ in the FSMF and $1.7 \%$ in the LMF. The spruce undergrowth was evenly distributed, $60-90 \%$, in the trial plots. Most of the young trees grew in the moss cover and some spruce were found on micro-relief sites (micro hills) formed from decaying wood.

Most of the spruce undergrowth formed xylorhizomes: FSMF, 90.0\%; SMF, 80.0\%; PMF, 87.0\%; and LMF, 77.0\%. Xylorhizome formation in spruce is similar to that in fir [34] and linden [48]. (The xylorhizome formation scheme was introduced earlier [33]). By age $20,96 \%$ of the spruce formed at least one adventitious root on the buried part of the stem. The xylorhizome formation resulted in a change to the relative size of the above-ground part of the plant (height above soil level) and its absolute length (including the buried parts). Depending on forest type, this ratio varied on average from 41 to $75 \%$, and the height of individual spruce was only $22 \%$ of the total height (above soil level plus buried part) (Table 2).

Spruce growth dynamics changed due to a large amount of suppressed undergrowth with xylorhizomes (Figure 2). The highest, but not statistically valid, increases in height and relative growth rates for undergrowth were found in the SMF and PMF, with minimal increases in the FSMF or LMF. Most spruce grew more than $50 \mathrm{~cm}$ and developed into large undergrowth only at age 32-33. In contrast, depending on the amount of light, the height of young Norway spruce (Picea abies (L.) H. Karst.) by age 35 may vary between 1 and $8 \mathrm{~m}$ [70]. According to other data, Norway spruce seedlings take 30-60 years to grow to $1.3 \mathrm{~m}$ [71,72]. Lin et al. [73] estimated that it takes 20-30 years for Norway spruce seedlings to grow to a height of $50 \mathrm{~cm}$ and extra 20-30 years to reach $1.3 \mathrm{~m}$. However, some spruce below the forest canopy in a supportive environment (especially under good light conditions) reached $50 \mathrm{~cm}$ by age 15 . The most suppressed undergrowth was represented by 30-35-year-old plants $9-11 \mathrm{~cm}$ tall. Having analyzed the growth dynamics in height and relative growth, which indicated a change in growth rate, we distinguished two periods of growth intensity (slow and stable) for the aerial part of spruce.

The peculiarity of the slow-growth period is that annual growth for the current year was less than for previous ones. This period ranged from 12 (PMF) to 18 (FSMF) years. There were significant differences in relative growth. The smallest, but statistically not valid, relative growth in spruce undergrowth occurred in permafrost habitats, indicating a lower growth rate.

During the stable growth period, the annual growth for the current year was equal to, or slightly higher than, that of previous years. There were no significant differences in relative growth during this period (age 12-18, depending on forest type), which continued through the study.

These two growth periods were associated primarily with the characteristics of the spruce habitat. At the earliest ontogenetic stages (the first 10-15 years), the undergrowth, on a bryophyte cover, must take water and nutrients from the latter. The root system 
gradually overcame the moss cover and entered the soil, after which the plant absorbed more nutrients and water and grew more quickly. Furthermore, growth rates were closely related to plant development. For example, much of the spruce undergrowth up to age 9-12 consisted of single-axis plants, which have very few shadow needles and cannot produce enough photosynthetic products. This explains the slow growth of spruce through the first period. By 9-10 years, more than $90 \%$ of the spruce had lateral branches that increased the assimilation surface, generated photosynthetic products, and contributed to growth. Crown growth occurred exponentially, with most plants forming third-order and pseudo-whorl branches.

Data relating the age of a tree to its ontogeny stage are highly inconsistent. The ash (Fraxinus excelsior L.) undergrowth in European Russia broad-leaved forests can grow to age 15 in the juvenile, up to 27 in the immature and up to 30 in the virginile stage [74]. The maximum age of spruce (Picea abies (L.) H. Karst.) undergrowth in spruce broad-leaved and pine forests of the "Bryansk forest" reserve (Central Russia) can reach 6 years in the juvenile, 25 years in the immature and 48 years in the virginile stage [75]. Under the adverse conditions of permafrost, Siberian spruce grow very slowly, and trees with a trunk diameter of $10 \mathrm{~cm}$ are maybe 100 years old or more [12].

We established that the most prolonged juvenile period in spruce lasted 20 years, and the immature period continued for as long as 50 (Table 3). These ages are critical for spruce undergrowth; if the plant does not cross into the following stage of ontogeny after approaching this age, it will die.

A woody plant's ontogeny contains morphological and functional features that reveal themselves in changes to its structural-functional characteristics at different stages throughout its life. These structures, or combinations thereof, are peculiar to a given ontogeny stage, but only when they exist can ontogeny stages be determined. Their appearance, signaling transition to the next stage, precedes determination (production and accumulation of matter), the acquisition of readiness for further growth (conclusion of several physiological-biochemical reactions), hidden or embryonic growth and development, and finally, apparent growth and progress. Simultaneously, the appearance of qualitative neogenesis leads to future changes in quantitative characteristics. It follows that plants must not only have morphological structures or their combinations unique to that stage, but also an equally diverse number of characteristics $[35,42,65]$.

The morphological criteria for recognizing the ontogeny stages of spruce are the first lateral (from juvenile to immature) and first pseudo-whorl (from immature to virginile) branches. Considering these criteria and the results of our research, we clarified the following stages of ontogeny in the pre-generative development of Siberian spruce: prejuvenile (sprouting), juvenile, immature and virginile.

\subsection{Pre-Juvenile Ontogeny Stage ( $p$ )}

The germinating ability of spruce seeds was quite significant (about $85 \%$ ). The first seedlings emerged from May to June, and seed sprouting was epigeal (i.e., occurred above ground). Seedlings stayed well preserved for several years because hygroscopic green mosses, which absorb moisture from precipitation and the air and have low thermal conductivity [76] protected them from drought and cold. Within the habitats, the average hypocotyl length was $2.6 \mathrm{~cm}$.

\subsection{Juvenile Ontogeny Stage ( $j$ )}

The mechanisms of shadow tolerance begin to appear early in conifers. In the Norway spruce example [77], variations in the red to far-red light ratio triggered changes in gene expression for hormone signaling and pigment biosynthesis, which further ensured this species would be resistant to shading. After wintering, the spruce moved to the juvenile stage. In spring, the apical bud of a one-year-old plant burst, and the stem started growing. During the second year, most of the plants examined did not break their lateral buds, and the central shoot (primary axis) did not branch. However, if the apical bud was damaged 
(for example, due to a late spring frost), one (even two or three) lateral bud (s) opened, from which replacement branches emerged. Over time, the strongest, most viable branch remained; the others dried up and died. Towards the end of the second growing season, the apical bud and two or three lateral buds reformed, usually at the upper part of the central shoot closer to the apical bud. The initiation of branching (formation of the first lateral shoots) depended on the type of forest. Most spruce undergrowth in the FSMF and SMF formed lateral shoots before age 9, while in the PMF and LMF, it was at 9-12. Microecological conditions of undergrowth settlement also affected the formation time of the first lateral shoot. In the third or fourth years, in a supportive microenvironment (micro hills from decaying wood or inside forest gaps), aside from the apical buds, one or two lateral buds opened at the central shoot. These spruce generated the first lateral shoot at this time and passed into the immature stage. The first lateral shoots in an adverse microhabitat began to form later, and only the apical bud opened annually. It is necessary to point out that in the juvenile spruce, the cotyledons were preserved during the first 3 to 6 years. They served as an extra assimilating surface and, to some extent, compensated for the undeveloped assimilation apparatus of such plants. An analysis of wood increments has shown that the juvenile period in conifers can last for the first 10-20 years [78], which is consistent with our data on the maximum age of young spruce at this stage.

\subsection{Immature Ontogeny Stage (im)}

The presence of lateral shoots and increased branching order are signs a plant has entered the immature stage. Ordinarily, one lateral shoot appears, but in rare cases two or three appear, and the spruce grows the primary axis and lateral branches. In addition to the apical bud, each lateral branch has 2-4 lateral buds that form on every annual shoot in its topmost part. However, the increase in the branching order is slow. In a supportive microenvironment, third-order branches appear at age 8 and the fourth-order at 18 . The growth and branching of lateral shoots are monopodial like the central shoot (primary axis). In addition to the apical bud, 1-4 lateral buds burst annually. The greater the branching order, the smaller their annual increments (e.g., third-order branches grow more slowly than second-order, fourth-order branches grow more gradually than third-order). In addition, a study of the growth of Sitka spruce (Picea sitchensis (Bong.) Carr.) and Douglas fir (Pseudotsuga menziesii Mirb. (Franco) var. menziesii) showed that shading below part of the crown slowed growth or killed branches (approximately half of the branches died) while the remaining branches continued to grow and develop [79-82]. When a spruce grows to 15-25 cm, it forms a well-developed, widely conical crown, sometimes umbrella-shaped. The conical crown has also been observed for other coniferous species [83]. The umbrellashaped crown forms in an adverse environment when lateral branch extension is greater than the increment of the primary shoot. Some shade-tolerant deciduous and coniferous species also change the shape and structure of the crown below the canopy [84,85]. We found that, with increasing age under these conditions, the height of the above-ground part of the immature spruce did not change, while other parameters (the length of the central shoot, including the buried part, the diameter of the shoot at the surface of the soil) increased. This phenomenon is linked to xylorhizome formation when the annual height increase becomes less noticeable as the buried part of the central shoot's size is enlarged.

\subsection{Virginile Ontogeny Stage (i)}

This stage starts with the pseudo-whorl shoot formations on the central axis and lasts until the first generative branches emerge. The early development of pseudo-whorl shoots is mainly observed in spruce growing in forest gaps, but under shadowy conditions, the formation time of these branches shifts to a later age. The buds of the pseudo-whorl branches formed on the central shoot, indicating that spruce began to grow under sufficient light conditions, mainly due to reduced competition from herbs and shrubs. The life expectancy of the pseudo-whorl branches declined with the illumination, but overall their existence is much shorter (5-15 years) than that of the whorl shoots (decades). Pseudo- 
whorl sprouts significantly raised the assimilating surface. Branches formed during the immature phase, gradually stopped, and died; only the strongest ones typically grew well through the early years of the transition to the virginile stage, where spruce can grow up to 80 years or more. The oldest we found was 85 .

Generalizing the results allowed us to identify some peculiarities in the pre-generative Siberian spruce ontogeny. In addition to being substantially diverse in linear size, the spruce undergrowth of the comparable biological age may be at various stages and vary in quality. There are two ways the spruce undergrowth develops, depending on the microenvironmental conditions (Figure 3). The "direct" way occurs in supportive environments, and is characterized by fast growth, accumulation of the most biomass, quick passage to successive stages, and, consequently, rapid capture of living space. It enables the undergrowth to settle and intensively develop new areas.

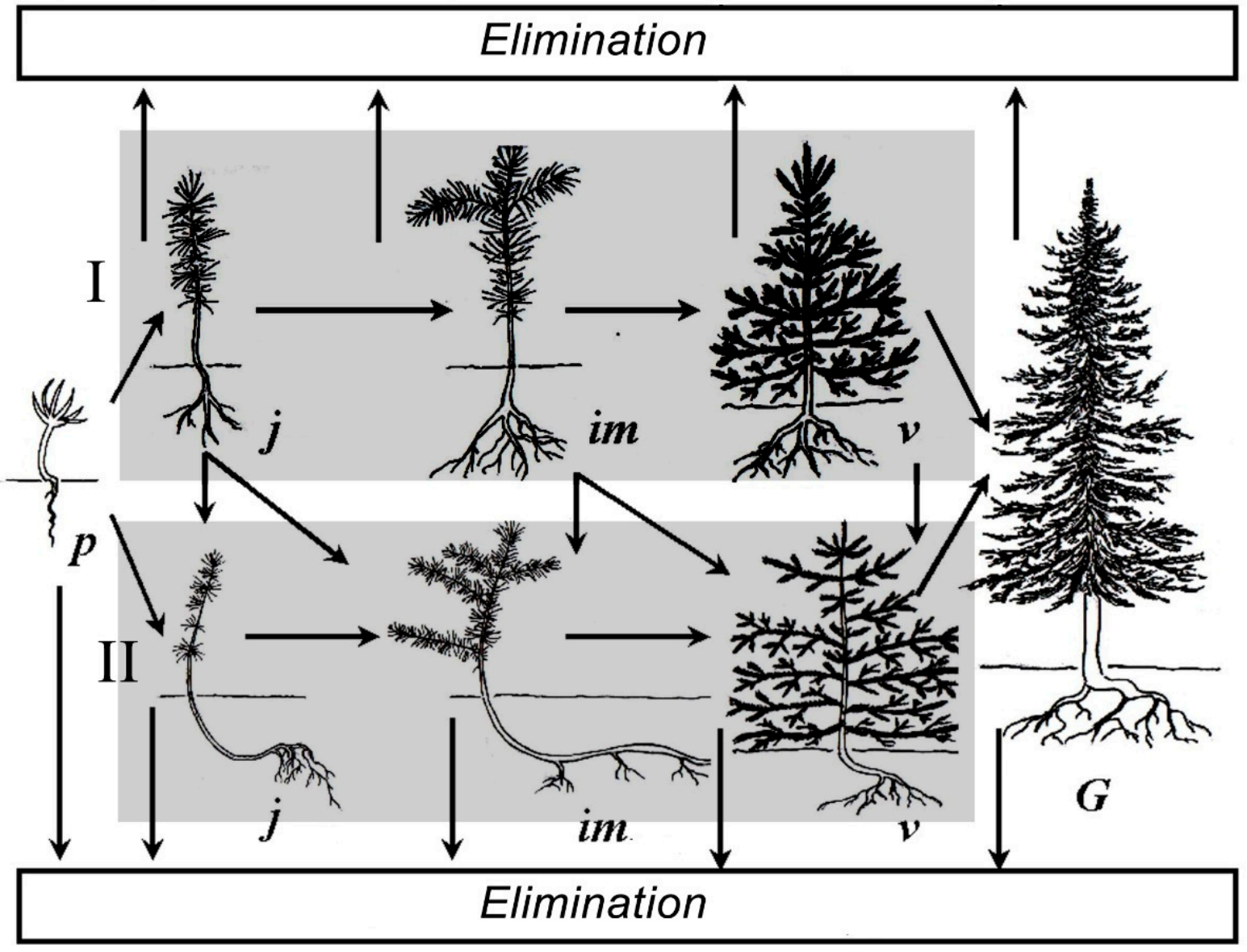

Figure 3. Scheme of the ontogeny of the Siberian spruce (Picea obovata Ledeb.).

Ways of development: I-in supportive environments ("direct" path); II-in adverse environments ("waiting" mode). Ontogeny states: $p=$ pre-juvenile (seedlings), $j=$ juvenile; im = immature; $v=$ virginile; $G=$ generative. The arrows indicate possible transitions.

When the environment does not allow spruce to grow along the direct path, the undergrowth goes into "wait" mode for improved growth and development conditions. Along this path, the undergrowth is suppressed and is characterized by three features: slow and steady growth, which allows it to outgrow the layers of bryophyte, grass and shrub gradually; a developmental delay in moving from one stage to the next; and the formation of a widely conical or umbrella-shaped crown to make maximum use of available sunlight energy.

The adaptive mechanism that permits a spruce to enter the waiting mode and survive for a long time is to form a xylorhizome. In a coenopopulation, these suppressed plants can 
hold territory, and if growth conditions improve, this undergrowth acts as the population's reserve. This property of shade-tolerant species (including the Picea genus) allows for competition for light compared to less tolerant species [86]. Hence, the direct or waiting growth pathway of the spruce undergrowth under the forest canopy is not static. If environmental conditions improve (i.e., primarily light), the undergrowth can pass from waiting to fast growth unless a critical age is approached at a given ontogeny stage. This transition is theoretically possible because forest gaps (where the lighting conditions are better) are known to be settled first by a new generation of plants rather than by large suppressed trees [87].

\section{Conclusions}

Our studies into spruce undergrowth under the forest canopy focused on morphological responses to the environment. We found that plants of similar biological age, growing in adverse conditions below the canopy, not only differed significantly in linear size but were in various stages of ontogeny. This age-range heterogeneity of undergrowth can be understood as an adaptation to preserve plant ontogeny.

Xylorhizome formation allowed the suppressed spruce to survive under adverse conditions for a long time. The presence of xylorhizomes caused changes to the size ratio of the above-ground (height above the soil) and the underground part of the plants, which affected growth dynamics because spruce undergrowth at identical linear dimensions was at different stages. We identified two growth strategies: a direct path of rapid growth and a waiting path in which the undergrowth remains in a suppressed state. These pathways allow the undergrowth to survive despite adverse environmental conditions. At the population level, spruce grows and develops in various ways, expands its ecological niche, reduces elimination under constantly changing environmental conditions, and maintains many plants, which ensures the stability of the spruce population.

Author Contributions: Conceptualization, A.K. (Alexey Kulagin) and G.Z.; methodology, A.D.; validation, A.D., G.Z. and A.K. (Andrey Kulagin); formal analysis, A.D., G.Z. and R.U.; investigation, A.D., G.Z., A.K. (Alexey Kulagin), R.G., R.U., N.E., R.S., M.K., A.K. (Andrey Kulagin) and O.T.; writing—original draft preparation, G.Z.; writing—review and editing, G.Z. and M.K.; visualization, A.D. and O.T.; supervision, A.K. (Alexey Kulagin); project administration, G.Z. and A.K. (Alexey Kulagin). All authors have read and agreed to the published version of the manuscript.

Funding: This research received no external funding.

Institutional Review Board Statement: Not applicable.

Informed Consent Statement: Not applicable.

Data Availability Statement: Not applicable.

Acknowledgments: We would like to thank all the colleagues who participated in this research in one way or another during the 12 years but were not included in the final authors' list.

Conflicts of Interest: The authors declare no conflict of interest.

\section{References}

1. Piovesan, G.; Biondi, F. On tree longevity. New Phytol. 2021. [CrossRef]

2. Usmanov, I.Y.; Rakhmankulova, Z.F.; Kulagin, A.Y. Ecological Physiology of Plants; Logos: Moscow, Russia, $2001 ;$ p. 224. (In Russian)

3. Dobrowolska, D. Effect of stand density on oak regeneration in flood plain forests in Lower Silesia, Poland. Forestry 2008, 81, 511-523. [CrossRef]

4. Oberhauser, U. Secondary forest regeneration beneath pine (Pinus kesiya) plantations in the northern Thai highland: A chronosequence study. For. Ecol. Manag. 1997, 99, 171-183. [CrossRef]

5. Emborg, J. Understorey light conditions and regeneration with respect to the structural dynamics of a near-natural temperate deciduous forest in Denmark. For. Ecol. Manag. 1998, 106, 83-95. [CrossRef]

6. Yu, F.; Wang, D.; Shi, X.; Yi, X.; Huang, Q.; Hu, Y. Effects of environmental factors on tree seedling regeneration in a pine-oak mixed forest in the Qinling Mountains, China. J. Mount. Sci. 2013, 10, 845-853. [CrossRef] 
7. Hunziker, U.; Brang, P. Microsite patterns of conifer seedling establishment and growth in a mixed stand in the southern Alps. For. Ecol. Manag. 2005, 205, 67-79. [CrossRef]

8. Peng, Y.Y.; Dang, Q.-L. Effects of soil temperature on biomass production and allocation in seedlings of four boreal tree species. For. Ecol. Manag. 2003, 180, 1-9. [CrossRef]

9. Götmark, F.; Fridman, J.; Kempe, G.; Norden, B. Broadleaved tree species in conifer-dominated forestry: Regeneration and limitation of saplings in southern Sweden. For. Ecol. Manag. 2005, 214, 142-157. [CrossRef]

10. Gabbasova, I.M.; Garipov, T.T.; Suleimanov, R.R.; Komissarov, M.A.; Khabirov, I.K.; Sidorova, L.V.; Nazyrova, F.I.; Prostyakova, Z.G.; Kotlugalyamova, E.Y. The influence of ground fires on the properties and erosion of forest soils in the Southern Urals (Bashkir State Nature Reserve). Eurasian Soil Sci. 2019, 52, 370-379. [CrossRef]

11. Craine, J.; Dybzinski, R. Mechanisms of plant competition for nutrients, water and light. Funct. Ecol. 2013, 27, 833-840. [CrossRef]

12. Farjon, A. A Handbook of the World's Conifers (2 Vols.); Brill: Leiden, The Netherlands, 2010; p. 1111. [CrossRef]

13. Ammer, C. Konkurrenz um Licht_Zur Entwicklung der Naturverjüngung im Bergmischwald; Forstliche Forschungsberichte: München, Germany, 1996; Volume 151, p. 198.

14. Knapp, A.; Smith, W. Factors influencing understory seedling establishment of Engelmann spruce (Picea engelmannii) and subalpine fir (Abies lasiocarpa) in southeast Wyoming. Can. J. Bot. 1982, 60, 2753-2761. [CrossRef]

15. Nakamura, T. Effect of bryophytes on survival of conifer seedlings in subalpine forests of central Japan. Ecol. Res. 1992, 7, 155-162. [CrossRef]

16. Lin, F.; Hao, Z.-Q.; Li, B.-H.; Ye, J.; Dai, G.-H.; Zhang, J.; Ni, W.-D. The relationship between the moss community characteristics and the regeneration in the dark coniferous forest of Changbai Mountain. Acta Ecol. Sin. 2007, 27, 1308-1314.

17. Takahashi, M.; Sakai, Y.; Ootomo, R.; Shiozaki, M. Establishment of tree seedlings and water-soluble nutrients in coarse woody debris in an old-growth Picea-Abies forest in Hokkaido, northern Japan. Can. J. For. Res. 2000, 30, 1148-1155. [CrossRef]

18. Iijima, H.; Shibuya, M.; Saito, H.; Takahashi, K. The effect of moss height on survival and growth of Picea jezoensis seedlings on fallen logs. J. For. Res. 2004, 86, 358-364. [CrossRef]

19. Iijima, H.; Shibuya, M. Evaluation of suitable conditions for natural regeneration of Picea jezoensis on fallen logs. J. For. Res. 2010, 15, 46-54. [CrossRef]

20. Narukawa, Y.; Iida, S.; Tanouchi, H.; Abe, S.; Yamamoto, S.-I. State of fallen logs and the occurrence of conifer seedlings and saplings in boreal and subalpine oldgrowth forests in Japan. Ecol. Res. 2003, 18, 267-277. [CrossRef]

21. Kupferschmid, A.D.; Bugmann, H. Effect of microsites, logs and ungulate browsing on Picea abies regeneration in a mountain forest. For. Ecol. Manag. 2005, 205, 251-265. [CrossRef]

22. Hisashi, S.; Nagaike, T. Microsites for seedling establishment of subalpine conifers in a forest with moss-type undergrowth on Mt. Fuji, central Honshu, Japan. Ecol. Res. 2005, 20, 678-685.

23. Bače, R.; Svoboda, M.; Pouska, V.; Janda, P.; Červenka, J. Natural regeneration in Central-European subalpine spruce forests: Which logs are suitable for seedling recruitment? For. Ecol. Manag. 2015, 266, 254-262. [CrossRef]

24. Alekseev, V.A. Forest Light Status; Nauka: Leningrad, Russia, 1975; p. 224. (In Russian)

25. Rabotnov, T.A. Dynamics of plant coenotic populations. In The Population Structure of Vegetation (Handbook of Vegetation Science); White, J., Ed.; Springer: Berlin/Heidelberg, Germany, 1985; Part 3, pp. 121-142.

26. Belyaeva, N.; Danilov, D. Development of undergrowth phenological spruce forms in different species composition of forest stands. In Proceedings of the 24th Annual International Scientific Conference "Research for Rural Development 2018", Jelgava, Latvia, 16-18 May 2018; pp. 117-124. [CrossRef]

27. Black, R.A.; Bliss, L.C. Reproductive ecology of Picea mariana (Mill.) BSP., at tree line near Inuvik, Northwest Territories, Canada. Ecol. Monog. 1980, 50, 331-354. [CrossRef]

28. Morneau, C.; Payette, S. Postfire lichen-spruce woodland recovery at the limit of the boreal forest in northern Quebec. Can. J. Bot. 1989, 67, 2770-2782. [CrossRef]

29. Rubtsov, M.V.; Glazunov, Y.B.; Nikolaev, D.K. Regenerative and age dynamic of spruce population in pine plantations under conditions typical for spruce development. Contemp. Probl. Ecol. 2016, 9, 884-893. [CrossRef]

30. Norton, D.A.; Ogden, J. Problems with the use of tree rings in the study of forest population dynamics. In Methods of Dendrochronology: Applications in the Environmental Sciences; Cook, E.R., Kairiukstis, L.A., Eds.; Kluwer Academic Publishers: Amsterdam, The Netherlands, 1990; pp. 284-288.

31. DesRochers, A.; Gagnon, R. Is ring count at ground level a good estimation of black spruce age? Can. J. For. Res. 1997, 27, 1263-1267. [CrossRef]

32. Niklasson, M. A comparison of three age determination methods for suppressed Norway spruce: Implications for age structure analysis. For. Ecol. Manag. 2002, 161, 279-288. [CrossRef]

33. Kulagin, A.Y.; Davydychev, A.N.; Zaitsev, G.A. Specific features of the growth of Siberian spruce (Picea obovata Ledeb.) at early stages of ontogeny in broadleaf-conifer forests of the Ufa Plateau. Rus. J. Ecol. 2006, 37, 66-69. [CrossRef]

34. Zaitsev, G.A.; Kulagin, A.Y.; Davydychev, A.N. The particularities of the growth of Siberian fir (Abies sibirica Ledeb.) in the first stages of ontogeny in conifer forests (Ufa plateau, Pre-Ural). Trees 2018, 32, 511-518. [CrossRef]

35. Bellassen, V.; Luyssaert, S. Carbon sequestration: Managing forests in uncertain times. Nature 2014, 506, 153-155. [CrossRef]

36. Huang, L.; Zhou, M.; Lv, J.; Chen, K. Trends in global research in forest carbon sequestration: A bibliometric analysis. J. Clean. Prod. 2020, 252, 119908. [CrossRef] 
37. Daigneault, A.; Favero, A. Global forest management, carbon sequestration and bioenergy supply under alternative shared socioeconomic pathways. Land Use Policy 2021, 103, 105302. [CrossRef]

38. Bastos, A.; Fleischer, K. Effects of rising $\mathrm{CO}_{2}$ levels on carbon sequestration are coordinated above and below ground. Nature 2021, 591, 532-534. [CrossRef]

39. Serebryakov, I.G. Ecological Morphology of Plants; Vysshaja Shkola: Moscow, Russia, 1962; p. 378. (In Russian)

40. Nukhimovskaya, Y.D. Ontogeny of Siberian fir (Abies sibirica Ledeb.) under the conditions of the Moscow region. Bull. Mosk. Obs. Ispyt. Prirody Otdel Biol. 1971, 76, 105-111. (In Russian)

41. Makhatkov, I.D. Polivariancy of Siberian fir ontogeny. Bull. Mosk. Obs. Ispyt. Prirody Otdel Biol. 1991, 96, 79-88. (In Russian)

42. Romanovskii, A.M. Polyvariation of Picea abies (Pinaceae) ontogeny in the Bryansk woodland. Bot. Zhurnal 2001, 86, 72-85. (In Russian)

43. Ukhvatkina, O.N.; Komarova, T.A.; Trofimova, A.D. The features of ontogenesis Picea ajanensis (Lindl. et Gord.) Fisch. ex Carr. in the middle part of southern Sikhote-Alin mountains. Lesnoi Vestnik 2010, 3, 169-173. (In Russian)

44. Nikolaeva, S.A.; Velisevich, S.N.; Savchuk, D.A. The ontogeny of Pinus sibirica in the southeast of the West Siberian Plain. Zhurnal Sib. Fed. Univ. Biol. 2011, 4, 3-12. (In Russian)

45. Ivanova, N.S.; Yermakova, M.V.; Zolotova, E.S. The initial stage of ontogenesis of Picea obovata Ledeb on different soil. Izvestia Samara Sci. Cent. Russ. Acad. Sci. 2016, 18, 5-11. (In Russian)

46. Stavrova, N.I.; Gorshkov, V.V.; Mishko, A.E. Ontogeny of Picea obovata (Pinaceae) in old-growth northern taiga dwarf shrub-green moss pine-spruce forests. Bot. Zhurnal 2017, 102, 163-185. (In Russian) [CrossRef]

47. Mishko, A.E. Ontomorphogenesis of Siberian Spruce (Picea obovata Ledeb.) in the North Taiga Forests (on the Example of the Kola Peninsula). Ph.D. Thesis, The Komarov Botanical Institute of the Russian Academy of Sciences, Saint Petersburg, Russia, 2019. (In Russian).

48. Kulagin, A.Y.; Shayakhmetov, I.F. Natural under-canopy regeneration and height-age structure of small-leaved linden (Tilia cordata Mill.) undergrowth in water-conservation forests around Pavlovskoe Reservoir, Ufa River. Rus. J. Ecol. 2007, 38, 247-252. [CrossRef]

49. Kulagin, Y.Z. About perennial frozen soils in the Bashkir TransUral Region. Ecologia 1976, 2, 24-29. (In Russian)

50. Mukatanov, A.H. Permafrost-affected soils of the Ufa Plateau. Pochvovedenie 1999, 7, 828-833. (In Russian)

51. Kangas, A. Mensurational aspects. In Forest Inventory: Methodology and Applications; (Managing Forest Ecosystems, vol. 10); Kangas, A., Maltamo, M., Eds.; Springer: Dordrecht, Germany, 2006; Chapter 4; pp. 53-63. [CrossRef]

52. Kershaw, J.A.; Ducey, M.J.; Beers, T.W.; Husch, B. Forest Mensuration, 5th ed.; Wiley: Chichester, UK, 2016; p. 613. [CrossRef]

53. Sukachev, V.N. Biogeology Research Program and Methodology; Nauka: Moscow, Russia, 1966; p. 333. (In Russian)

54. Yarmishko, V.T. Selection and establishment of permanent test areas in forest communities. In Methods of Studying Forest Communities; Andreeva, E.N., Bakkal, I.Y., Gorshkov, V.V., Lianguzova, I.V., Maznaya, E.A., Neshataev, V.U., Neshataeva, V.U., Stavrova, N.I., Yarmishko, V.T., Yarmishko, M.A., Eds.; Research Institute of Chemistry of St. Petersburg State University: Saint Petersburg, Russia, 2002; pp. 33-37. (In Russian)

55. Kangas, A.; Maltamo, M. Forest Inventory: Methodology and Applications; (Managing Forest Ecosystems, vol. 10); Springer: Dordrecht, Germany, 2006; p. 362. [CrossRef]

56. Newton, A.C. Forest Ecology and Conservation: A Handbook of Techniques; Oxford University Press: New York, NY, USA, 2007; p. 480. [CrossRef]

57. Anuchin, N.P. Forest Inventory, 5th ed.; Forest industry: Moscow, Russia, 1982; p. 552. (In Russian)

58. Pridnya, M.V. A trial in determining the age of Picea obovata advance growth with the help of pith nodes. Lesovedenie 1967, 5, 72-77. (In Russian)

59. Sirén, G. Alikasvoskuusten biologiaa. Summary: On the biology of undergrown spruce. Acta. For. Fenn. 1950, 58, 1-90. [CrossRef]

60. Chojnacki, W. O metodzie dokladnego okreslenia wieku podrostow i rocznych przyrostow u niektorych gatunkow drzew lesnych (About the method to determine accurately the age of saplings and the annual height growth of some forest tree species). Sylwan 1964, 1, 71-76.

61. Ross, S.M. Introduction to Probability and Statistics for Engineers and Scientists, 4th ed.; Elsevier Academic Press: San Diego, CA, USA, 2009; p. 680. [CrossRef]

62. Gatsuk, L.E.; Smirnova, O.V.; Vorontzova, L.I.; Zaugolnova, L.B.; Ztiukova, L.A. Age states of plants of various growth forms: A review. J. Ecol. 1980, 68, 675-696. [CrossRef]

63. Schitt, P.G. Study of the Growth and Development of Fruit and Berryplants; Selkhozgiz: Moscow, Russia, 1958; p. 447. (In Russian)

64. Rabotnov, T.A. The life cycle of perennial herbaceous plants in meadow coenoses. In Geobotany; Lavrenko, E.M., Sokolov, S.Y., Shennikov, A.P., Eds.; Nauka: Moscow, Russia, 1950; Volume 6, pp. 7-204. (In Russian)

65. Uranov, A.A. Age spectrum of the phytocoenopopulation as a function of time and energetic wave processes. Biol. Nauki 1975, 2, 7-34. (In Russian)

66. Smirnova, O.V.; Zaugolnova, L.B.; Ermakova, I.M. Plant Coenopopulations (Basic Concept and Structure); Nauka: Moscow, Russia, 1976; p. 217. (In Russian)

67. Komarov, A.S.; Palenova, M.M.; Smirnova, O.V. The concept of discrete description of plant ontogenesis and cellular automata models of plant populations. Ecol. Model. 2003, 170, 427-439. [CrossRef] 
68. Smirnova, O.V.; Chistyakova, A.A.; Zaugolnova, L.B.; Evstigneev, O.I.; Popadiouk, R.V.; Romanovsky, A.M. Ontogeny of a tree. Bot. Zhurnal 1999, 84, 8-19. (In Russian)

69. Evstigneev, O.; Korotkov, V.N. Ontogenetic stages of trees: An overview. Rus. J. Ecosys. Ecol. 2016, 1. [CrossRef]

70. Dănescu, A.; Kohnle, U.; Bauhus, J.; Weiskittel, A.; Albrecht, A.T. Long-term development of natural regeneration in irregular, mixed stands of silver fir and Norway spruce. For. Ecol. Manag. 2018, 430, 105-116. [CrossRef]

71. Nilsen, P. Selective Cutting in Mountain Spruce Forest-Regeneration and Production After Earlier Cuttings; Norwegian Forest Research Institute: As, Norway, 1984; p. 26.

72. Lundqvist, L.; Nilson, K. Regeneration dynamics in an uneven-sized virgin Norway spruce forest in northern Sweden. Scand. J. For. Res. 2007, 22, 304-309. [CrossRef]

73. Lin, C.J.; Laiho, O.; Lähde, E. Norway spruce (Picea abies L.) regeneration and growth of understory trees under single-tree selection silviculture in Finland. Eur. J. Forest. Res. 2012, 131, 683-691. [CrossRef]

74. Zaugolnova, L.B. Age states in the ontogeny of ash (Fraxinus excelsior L.). In Problems of Morphogenesis of Flowering Plants and the Composition of Their Populations; Uranov, A.A., Ed.; Nauka: Moscow, Russia, 1968; pp. 81-102. (In Russian)

75. Evstigneev, O.I.; Korotkova, N.V. Features of undergrowth development in Eastern European forests. Rus. J. Ecosys. Ecol. 2019, 4. [CrossRef]

76. Benninghoff, W.S. Interaction of vegetation and soil frost phenomena. Arctic 1952, 5, 34-44. [CrossRef]

77. Ranade, S.S.; Delhomme, N.; García-Gil, M.R. Transcriptome analysis of shade avoidance and shade tolerance in conifers. Planta 2019, 250, 299-318. [CrossRef]

78. Dinwoodie, J.M. Timber: Its Nature and Behavior, 2nd ed.; CRC Press: London, UK, 2000; p. 272. [CrossRef]

79. Ishii, H.; McDowell, N. Age-related development of crown structure in coastal Douglas-fir trees. For. Ecol. Manag. 2002, 169, 257-270. [CrossRef]

80. Ishii, H.T.; Ford, E.D.; Kennedy, M.C. Physiological and ecological implications of adaptive reiteration as a mechanism for crown maintenance and longevity. Tree Physiol. 2007, 27, 455-462. [CrossRef]

81. Pelt, R.V.; Sillett, S.C. Crown development of coastal Pseudotsuga menziesii, including a conceptual model for tall conifers. Ecol. Monogr. 2008, 78, 283-311. [CrossRef]

82. Kramer, R.D.; Sillett, S.C.; Van Pelt, R.; Franklin, J.F. Neighborhood competition mediates crown development of Picea sitchensis in Olympic rainforests: Implications for restoration management. For. Ecol. Manag. 2019, 441, 127-143. [CrossRef]

83. Tomlinson, P.B. Tree architecture: New approaches help to define the elusive biological property of tree form. Am. Sci. 1983, 71, 141-149.

84. Canham, C.D. Growth and canopy architecture of shade-tolerant trees: Response to canopy gaps. Ecology 1988, 69, 786-795. [CrossRef]

85. Pretzsch, H. The effect of tree crown allometry on community dynamics in mixed-species stands versus monocultures. a review and perspectives for modeling and silvicultural regulation. Forests 2019, 10, 810. [CrossRef]

86. Bartkowicz, L.; Paluch, J. Co-occurrence of shade-tolerant and light-adapted tree species in uneven-aged deciduous forests of southern Poland. Eur. J. Forest. Res. 2019, 138, 15-30. [CrossRef]

87. Leemans, R. Canopy gaps and establishment patterns of spruce (Picea abies (L.) Karst.) in two old-growth coniferous forests in central Sweden. Vegetatio 1991, 93, 157-165. [CrossRef] 